Materiales de Construcción

Vol. 68, Issue 331, July-September 2018, e164

ISSN-L: 0465-2746

https://doi.org/10.3989/mc.2018.07417

\title{
Viability of the use of construction and demolition waste aggregates in alkali-activated mortars
}

\author{
M.M. Alonso $\bowtie$, A. Rodríguez, F. Puertas \\ Eduardo Torroja Institute for Construction Sciences (IETcc-CSIC). Madrid (Spain) \\ $\triangle$ mmalonso@ietcc.csic.es
}

Received 13 july 2017

Accepted 16 January 2018

On line first 9 july 2018

\begin{abstract}
This study explores the technological feasibility of using construction and demolition waste $(\mathrm{C} \& D W)$ as recycled aggregate in alkali activated mortars, ascertaining the mechanical and microstructural behavior. Shrinkage behavior of alkali activated slag mortars (AAS) and fire resistance of alkali activated fly ash (AAFA) incorporating recycled aggregates have been also tested Normalized siliceous sand and two types of recycled concrete aggregates were used in the mixes at different proportions. The findings showed that water demand was higher in mortars prepared with recycled aggregate. Partial replacement $(20 \%$ - 80/20) of conventional aggregate with the recycled material was also observed to yield mortars with high mechanical strength, although total porosity also rose. Total replaclement, gave worse mechanical performance however. Fire resistance and shrinkage studies conducted indicated that alkaline cement mortars prepared with 80/20 recycled aggregated exhibit acceptable performance.
\end{abstract}

KEYWORDS: Mortars; Alkali activated mortars; Construction and demolition waste (C\&DW) aggregates; Mechanical performance; Fire resistance; Shrinkage

Citation/Citar como: Alonso, M.M.; Rodríguez, A.; Puertas, F. (2018) Viability of the use of construction and demolition waste aggregates in alkali-activated mortars. Mater. Construcc. 68 [331], e164 https://doi.org/10.3989/mc.2018.07417

RESUMEN: Utilización de áridos procedentes de residuos de construcción y demolición en morteros activados alcalinamente. Este estudio explora la viabilidad tecnológica del uso de residuos de construcción y demolición (C \& DW) como árido reciclado en morteros activados alcalinamente, determinando el comportamiento mecánico y microestructural. Asimismo, se determinó la retracción sufrida por morteros de escoria activados alcalinamente (AAS) y la resistencia al fuego de morteros de cenizas volantes activadas alcalinamente (AAFA) con incorporación de estos áridos reciclado. Se utilizó arena silícea normalizada y dos tipos de áridos de hormigón reciclado en diferentes proporciones. Los resultados mostraron que la demanda de agua era más alta en los morteros preparados con árido reciclado. También se observó que el reemplazo parcial con un 20\% (80/20) del árido convencional con el material reciclado producía morteros con alta resistencia mecánica, aunque la porosidad total también aumentaba. El reemplazo total, sin embargo, dio peor rendimiento mecánico. Los estudios de resistencia al fuego y retracción realizados, indicaron que los morteros de cementos activados alcalinamente preparados con áridos reciclados en proporción 80/20 presentan un rendimiento aceptable.

PALABRAS CLAVE: Morteros; Morteros activados alcalinamente; Residuos de Construcción y demolición (C\&DW); Prestaciones mecánicas; Resistencia a fuego; Retracción.

ORCID ID: M.M. Alonso (http://orcid.org/0000-0001-9096-752X); A. Rodríguez (http://orcid.org/0000-0003-08161557); F. Puertas (http://orcid.org/0000-0002-4215-0184)

Copyright: (C) 2018 CSIC. This is an open-access article distributed under the terms of the Creative Commons Attribution 4.0 International (CC BY 4.0) License 


\section{INTRODUCTION}

Construction industry is an important activity that entails a sizeable environmental problem. On the one hand, the associated quarrying of raw materials for ordinary portland cement (OPC) and natural aggregate (NA) for concrete leaves unsightly scars on the landscape. Moreover, large quantities of greenhouse gases are emitted in concrete manufacture (1). Also high rates of housing and infrastructure remodelling have led to the generation of large amounts of construction and demolition waste (C\&DW) (2), which is stockpiled in landfills. Actions are therefore needed to ensure resource conservation and construction industry sustainability (3) and to reach the Economy Circular Strategy according to EU (4). The avenues for attaining that objective include shrinking the amount of waste generated and furthering the reuse of stockpiled industrial by-products with especially attention to reuse of C\&DW in mortar and concrete manufacture.

The development of alkaline cements and concretes (also called geopolymers or alkali-activated materials, AAMs) (5-7) are lied within these lines of action. AAM mortars and concretes are known to feature high mechanical strength, which varies essentially with the starting aluminosilicate, alkaline activator composition and concentration, curing conditions and preparation $(8,9)$. Two of the most important alkaline cements are those provenient from alkali activated slag (AAS) and alkali activated fly-ash (AAFA)

Another possible sustainability measure is to reuse C\&DW to produce recycled aggregate (RA) as a partial or total replacement for natural aggregate (NA) in concrete manufacture (10). The properties of recycled aggregate differ depending on the origin of the waste and its majority constituent (demolished concrete structures, concrete with clay-based materials, clay-based construction materials, and asphalt or similar). Recycled aggregate is apt for a variety of applications, from road sub-bases, precast concrete, pavements and masonry mortars $(11,12)$. As a rule, RA is believed to lower portland cement mortar and concrete mechanical strength reports $(10,13,14)$ due essentially to its higher water demand and the weaker bonds formed with the cementitious matrix by recycled than natural aggregate due to the presence of mortar adheried to coarse recycled aggregate.

The possible combination of alkaline cements or geopolymers and recycled construction waste aggregate would constitute a further step toward sustainability. Previous works have studied the feasibility of using construction and demolition wastes as precursors for alkaline activated materials, with results in same cases contradictory. Puertas et al. (15) activated six different ceramic waste materials with $\mathrm{NaOH}$ and waterglass solutions, although no great compressive strengths were obtained in these pastes.
Also Allahverdi and Kani (16) activated mixtures of waste brick and concrete, and they concluded that the higher the $\mathrm{Na}_{2} \mathrm{O}$ by weight of dry binder, the higher the compressive strength of the pastes.

Reig et al (17) activated red clay ceramic with $\mathrm{NaOH}$ and waterglass solutions, obtaining mortars with compressive strengths up to $50 \mathrm{MPa}$ after seven curing days, due to optimization of $\mathrm{SiO}_{2} / \mathrm{Na}_{2} \mathrm{O}$ ratio, as well as water/binder and binder/sand ratios. These C\&DW has been used also for blended alkaliactivated materials. $\mathrm{NaOH}$ and $\mathrm{NaOH}+\mathrm{Wg}$ alkali activated pastes prepared with red clay brick waste (RCBW) and with differenten proportions of OPC as source of $\mathrm{CaO}$ increased the strength of the cements in comparison with alkali activated pastes with $100 \%$ RCBW (18). It has also been proven, that the addition of $40 \%$ RCBW improves the mechanical performance of blended AAS pastes and mortars (19).

However, little has been published to date on the use of such waste as an aggregate in alkaline slag or fly ash cement mortars and concretes and in some cases contradictory. Puertas et al (2) concluded that the performance of AAMs mortars with C\&DW aggregate depend on the nature of the binder (slag or fly ash) and the replacement ratio used. The use of recycled coarse aggregates (RCA) in FA geopolymer concrete (20) showed that mechanical strength and elastic modulus decrease with an increase in RCA content. As a general rule, the replacement of siliceous sand by C\&DW aggregate lowered mechanical strengths in AAS and AAFA mortars. Parthiban et al (21) studied the influence of RCA on AAS concretes. They observed that the replacement up to $100 \%$ of NA presented very good performance. In order to obtain such better results, they pre-wetted and saturated RCA and also, they used superplasticizers to avoid negative effects, such as reduced workability and poor mechanical performance.

Moreover, the effect of recycled construction and demolition waste aggregate on AAS and AAFA mortar and concrete mechanical strength is not the only knowledge gap that must be addressed: its effect on mortar and concrete microstructure and other properties must also be ascertained. This study therefore addressed the mechanical strength, drying shrinkage, microstructure and fire resistance behavior of alkaline cement mortars containing $20 \%$ or $100 \%$ of fine recycled aggregate, consisting in construction and demolition waste. OPC mortars were used as a control.

\section{EXPERIMENTAL}

\subsection{Materials}

Three binders were used: A blast furnace slag (BFS), a Coal fly ash (FA) and a CEM I 52.5R cement (OPC). Table 1 gives the chemical composition determined by XRF on PHILIPS PW-1004 
TABLE 1. Chemical composition of OPC, BFS and FA (wt. \%)

\begin{tabular}{lccc}
\hline \% weigth & OPC & BFS & FA \\
\hline $\mathrm{CaO}$ & 63.22 & 38.52 & 2.72 \\
$\mathrm{SiO}_{2}$ & 18.90 & 38.27 & 54.44 \\
$\mathrm{Al}_{2} \mathrm{O}_{3}$ & 4.41 & 11.80 & 27.51 \\
$\mathrm{~K}_{2} \mathrm{O}$ & 0.82 & 0.46 & 3.13 \\
$\mathrm{Na}_{2} \mathrm{O}$ & 0.10 & 0.40 & 0.52 \\
$\mathrm{Fe}_{2} \mathrm{O}_{3}$ & 3.91 & 1.04 & 6.38 \\
$\mathrm{MgO}$ & 1.68 & 8.31 & 1.51 \\
$\mathrm{TiO}_{2}$ & 0.25 & 0.39 & 1.27 \\
$\mathrm{P}_{2} \mathrm{O}_{5}$ & 0.09 & - & 0.31 \\
$\mathrm{SO}_{3}$ & 3.30 & 0.99 & - \\
$\mathrm{MnO}$ & - & 0.26 & 0.08 \\
\hline $\mathrm{LOI}$ & 2.35 & - & 2.10 \\
Free CaO & 1.40 & - & - \\
Vitreous content & - & 99 & 87.75 \\
\hline
\end{tabular}

LOI - Loss on ignition

TABLE 2. Particle size distribution and Blaine fineness for $\mathrm{OPC}, \mathrm{BFS}$ and FA

\begin{tabular}{lcccc}
\hline & $\begin{array}{c}\text { D10 } \\
(\mathbf{1 0} \% \text { of } \\
\text { sample } \\
\text { smaller than }) \\
(\boldsymbol{\mu m})\end{array}$ & $\begin{array}{c}\text { D50 } \\
\mathbf{5 0 \%} \text { of } \\
\text { sample } \\
\text { smaller than }) \\
(\boldsymbol{\mu m})\end{array}$ & $\begin{array}{c}\text { D90 } \\
\mathbf{( 9 0 \% \text { of }} \\
\text { sample } \\
\text { smaller than }) \\
(\boldsymbol{\mu m})\end{array}$ & $\begin{array}{c}\text { Blaine } \\
\text { fineness } \\
\mathbf{m}^{2} / \mathbf{k g}\end{array}$ \\
\hline OPC & 1.65 & 10.71 & 35.48 & 425 \\
BFS & 1.68 & 10.52 & 32.53 & 325 \\
FA & 2.35 & 15.08 & 58.59 & 202 \\
\hline
\end{tabular}

join to loss on ignition (22) and free lime of OPC (23). Vitreous content of BFS was found through McMaster method as modified by Hooton and Emery (24), while vitreous content of FA was determined with a selective attack with $1 \% \mathrm{HF}(25)$.

Particle sizes below which $10 \%, 50 \%$ and $90 \%$ of the distribution fell, as well as the Blaine fineness values for each sample (26) are listed in Table 2.

Three types of fine aggregates were used in this study: one was siliceous (S) and two aggregates $(\mathrm{R}$ and $\mathrm{H})$ from recycled construction and demolition waste $(C \& D W)$. H aggregate come from concrete waste, while $\mathrm{R}$ aggregate, has also ceramic particles. Their chemical composition is listed in Table 3. Solubles $\mathrm{SO}_{3}(27)$ and $\mathrm{Cl}^{-}$total content (28) in these recycled aggregates were also determined.

The mineralogical composition of the fines, determined by XRD on Philips PW1710 X-ray diffractometer, and the respective quantitative Rietveld analysis are given in Table 4. Further to the data in Table 3, aggregate $\mathrm{S}$ was siliceous, with over $98 \%$ quartz in its composition. Aggregate R comprised mostly calcite and dolomite, although smaller percentages of basanite, quartz and muscovite were also identified. Aggregate $\mathrm{H}$ consisted essentially of dolomite
TABLE 3. Chemical composition of fine aggregates $S, R$ and $\mathrm{H}($ wt. \%)

\begin{tabular}{lccc}
\hline \% weigth & S & R & H \\
\hline $\mathrm{CaO}$ & 0.1 & 30.62 & 31.15 \\
$\mathrm{SiO}_{2}$ & 96.8 & 15.66 & 6.12 \\
$\mathrm{Al}_{2} \mathrm{O}_{3}$ & 1.5 & 4.41 & 1.71 \\
$\mathrm{~K}_{2} \mathrm{O}$ & 0.6 & 0.76 & 0.27 \\
$\mathrm{Na} 2 \mathrm{O}$ & - & 0.20 & 0.21 \\
$\mathrm{Fe}_{2} \mathrm{O}_{3}$ & 0.4 & 1.77 & 0.72 \\
$\mathrm{MgO}$ & - & 8.14 & 16.62 \\
$\mathrm{MnO}$ & - & 0.02 & - \\
$\mathrm{TiO}_{2}$ & - & 0.23 & 0.09 \\
$\mathrm{P}_{2} \mathrm{O}_{5}$ & - & 0.07 & - \\
$\mathrm{SO}_{3}$ & - & 5.29 & 0.73 \\
$\mathrm{SrO}_{\mathrm{ZnO}}$ & - & 0.17 & 0.02 \\
$\mathrm{LOI}$ & - & 0.01 & 0.01 \\
$\mathrm{Soluble} \mathrm{SO}_{3}$ & - & 32.7 & 42.6 \\
$\mathrm{Cl}-$ & - & 6.1 & 1.5 \\
\hline
\end{tabular}

LOI - Loss on ignition

TABLE 4. Quantitative mineralogical composition of aggregates (wt. \%)

\begin{tabular}{lccc}
\hline \% weigth & S & R & H \\
\hline Quartz & 98.3 & 7.6 & 2.7 \\
Microcline & 1.7 & - & - \\
Calcite & - & 35.6 & 16.1 \\
Dolomite & - & 36.5 & 79.9 \\
Basanite & - & 12.8 & - \\
Muscovite & - & 7.4 & 1.3 \\
\hline
\end{tabular}

TABLE 5. Physical properties of the aggregates

\begin{tabular}{lccc}
\hline \% weigth & S & R & H \\
\hline Humidity (\%) & 0.1 & 7.1 & 4.5 \\
Water absorption (\%) & 0.1 & 3.7 & 3.3 \\
Density (g/mL) & 2.6 & 2.5 & 2.6 \\
\hline
\end{tabular}

(around $80 \%$ of the total) and calcite $(16 \%)$, with quartz and muscovite as minority crystalline phases.

Given the dolomitic nature of these aggregates, it would be logical to think that they could be reactive to alkali-aggregate reaction. These recycled aggregates come originally from dolomitic aggregates of the area of Granada (Spain) that have been analyzed in various studies, resulting in non-reactive aggregates $(29,30)$.

Physical characteristics (31) of the three types of aggregate used to prepare the mortars are summarised in Table 5. Their particle size distribution through differencial sieving (32) is plotted 
in Figure 1. Figure 2 shows the visual aspect of each particle size group, after differential sieving, where it is possible to observe, due to its more reddish color, that aggregate $\mathrm{R}$ contains ceramic particles.

\subsection{Mortar preparation and tests conducted}

Portland cement (OPC) and alkali-activated slag (AAS) and fly ash (AAFA) mortars were prepared at an aggregate/binder ratio of 2:1. Five mortars were prepared with each binder: one with 100\% siliceous sand (S), one with $100 \%$ aggregate $\mathrm{R}$, one with $100 \%$ aggregate $\mathrm{H}$ and the other two with $80 \% \mathrm{~S}$ and $20 \%$ recycled aggregate $\mathrm{R}$ or $\mathrm{H}$. OPC and AAFA mortars were mixed and prepared according to UNE-EN 196-1 (33). However, according to previous works (34) (35), longer mixing time (20 minutes) were used for AAS mortars to avoid fast setting and changes in rheology due to, mainly, primary a type of C-S-H gel formation (36). Liquid/Solid (L/S) ratios were determined for each mortar, based on slump test results. The liquid/solid ratios for the mortars were determined further to Spanish standard (37) to

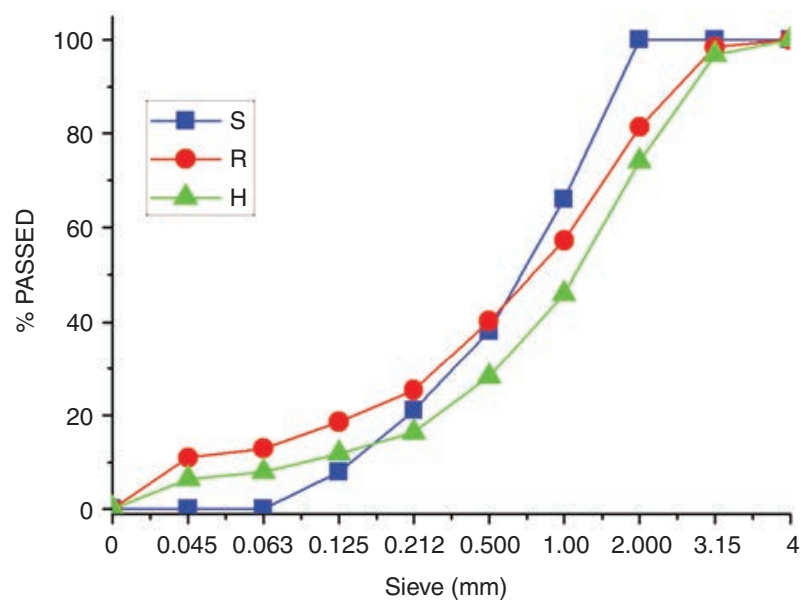

Figure 1. Particle size distribution for aggregates $\mathrm{S}, \mathrm{R}$ and $\mathrm{H}$. ensure the same slump and therefore, same consistency in all the materials.

The OPC mortars were water-hydrated while AAS mortars were activated with a waterglass solution $(\mathrm{Wg})\left(\mathrm{Na}_{2} \mathrm{O} \cdot \mathrm{nSiO}_{2} \cdot \mathrm{mH}_{2} \mathrm{O}+\mathrm{NaOH}\right)$ with $\mathrm{SiO}_{2} / \mathrm{Na}_{2} \mathrm{O}$ ratio of 1.2 and $4 \% \mathrm{Na}_{2} \mathrm{O}$ by mass of slag mass and, finally AAFA mortars were activated with a $10 \mathrm{M}$ solution of $\mathrm{NaOH}$ containing $15 \% \mathrm{Wg}$.

OPC and AAS mortars were cured at $99 \% \mathrm{RH}$ and $20 \pm 2{ }^{\circ} \mathrm{C}$ for $24 \mathrm{~h}$ (OPC mortars were submerged in water, until the test age). AAFA were cured in an oven at $85{ }^{\circ} \mathrm{C}$ and $99 \%$ relative humidity for the first 20 hours. They were subsequently removed from the moulds and stored in a climatic chamber in the same conditions as the AAS mortar specimens. Table 6 lists the OPC, AAS and AAFA mortars prepared.

TABLE 6. OPC, AAS and AAFA mortar batching

\begin{tabular}{lcccl}
\hline & \multicolumn{3}{c}{ Fine aggregate (\% weight) } & \\
\cline { 2 - 4 } Binder & $\mathbf{S}$ & $\mathbf{R}$ & $\mathbf{H}$ & Sample name \\
\hline OPC & 100 & - & - & OPC100S \\
& - & 100 & - & OPC100R \\
& - & - & 100 & OPC100H \\
& 80 & 20 & - & OPC80:20S/R \\
& 80 & - & 20 & OPC80:20S/H \\
AAS & 100 & - & - & AAS100S \\
& - & 100 & - & AAS100R \\
& - & - & 100 & AAS100H \\
& 80 & 20 & - & AAS80:20S/R \\
AAFA & 80 & - & 20 & AAS80:20S/H \\
& 100 & - & - & AAFA100S \\
& - & 100 & - & AAFA100R \\
& - & - & 100 & AAFA100H \\
& 80 & 20 & - & AAFA80:20S/R \\
& 80 & - & 20 & AAFA80:20S/H \\
\hline
\end{tabular}
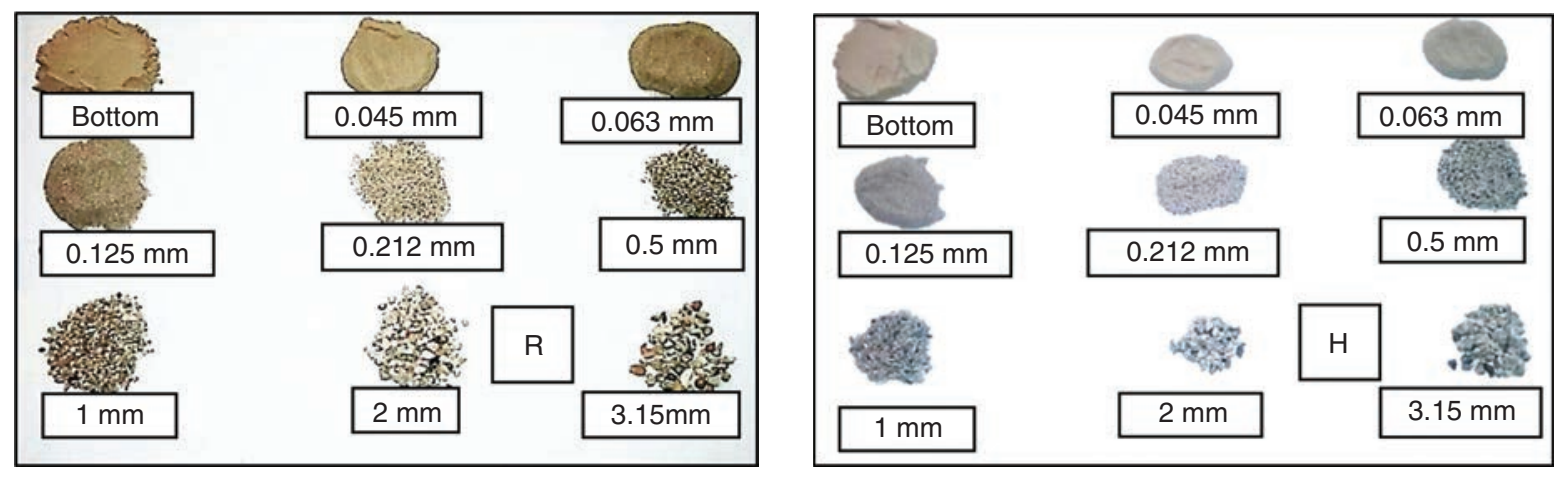

FIgURE 2. Aggregate $\mathrm{R}$ and $\mathrm{H}$ particles. 


\section{- Mechanical strength and porosity of AAMs}

Mechanical strengths of all mortars prepared were found for the 2,7 and 28-day mortar specimens $(4 \times 4 \times 16 \mathrm{~cm})$ in a Ibertest press. Total porosity and pore size distribution were tested in the 7 day specimens with $20 \%$ replacement on a Micromeritics 9320 Porosimeter.

\section{- Shrinkage behaviour of AAS mortars}

AAS mortar shrinkage was studied on prismatic specimens measuring $2.5 \times 2.5 \times 28.7 \mathrm{~cm}$ using a Mitutoyo Absolute $\mathrm{C} 112 \mathrm{mxb}$ retractometer. These specimens were cured as described above for the first 24 hours and subsequently stored in climatic chambers at $22 \pm 2{ }^{\circ} \mathrm{C}$ and at either 99 or $45 \% \mathrm{RH}$. The tests were conducted until 120-160 days.

\section{- Fire resistance of AAFA mortars}

Three-centimetre cubic specimens were prepared for the AAFA fire resistance tests. After curing for 28 days in the conditions described above, they were kept in a kiln at $50{ }^{\circ} \mathrm{C}$ for $24 \mathrm{~h}$ to eliminate any residual moisture. They were subsequently heated to $200,400,600,800$ and $1000{ }^{\circ} \mathrm{C}$, ramping at a rate of $6{ }^{\circ} \mathrm{C} / \mathrm{min}$ and holding the temperature constant for $1 \mathrm{~h}$ at each plateau. Specimen weight and compressive strength were determined.

\section{RESULTS AND DISCUSSION}

\subsection{Slump tests. Determination of optimal liquid/ solid ratio}

Figure 3 gives the liquid/solid ratios used for the mortars based on slump test results.

Figure 3 shows that the replacement of S aggregate by $\mathrm{R}$ or $\mathrm{H}$ recycled aggregates increased liquid demand for all mortars, and this increment is higher as the replacement percentage raises. This effect has been previously reported by other authors (38). Corinaldesi and Moriconi (39), studying the amount of water needed to prepare OPC mortars with different types of recycled aggregate, observed that at $100 \%$ replacement, the $1 / \mathrm{s}$ ratio climbed by 19 to $52 \%$. Conversely, other authors who maintained the same $1 / \mathrm{s}$ ratio observed that mortar slump values declined more steeply when more recycled aggregate was used. This effect depends on the nature of the recycled aggregate, its water absorption and shape, particularly in clay-based aggregate rate $(38,40)$.

The 1/s ratio obtained for each type of OPC mortars is lower that found for corresponding AAS and AAFA mortars. This effect in mortars with aggregate/binder ratio of 2:1, was previously described by Alonso et al (36).

In OPC mortars, the replacement of aggregate $\mathrm{S}$ with $100 \% \mathrm{R}$ or $\mathrm{H}$ increased the $1 / \mathrm{s}$ ratio by 51 and $39 \%$, respectively. In AAS mortars this increase was found to be around 32 and $16 \%$ for $100 \% \mathrm{R}$ and $\mathrm{H}$ replacement respectively. In AAFA mortars, 100\% replacement of S aggregate result in highest increase of liquid to solid ratio ( 76 and $64 \%$ for $\mathrm{R}$ and $\mathrm{H}$ aggregates respectively).

The replacement of aggregate $\mathrm{S}$ with $20 \% \mathrm{R}$ or $\mathrm{H}$ called for raising the 1/s ratio in OPC and AAFA by 7 and $25 \%$, respectively. The $1 / \mathrm{s}$ ratio increased sigthly when 80/20 recycled C\&DW aggregate replacement was added to AAS mortars, however (see Figure 3), even though the liquid required in these mortars was greater than in the OPC and AAFA materials. This finding may be associated with the nature and properties of the activating solution. However, at 20\% replacement, no differences were observed between

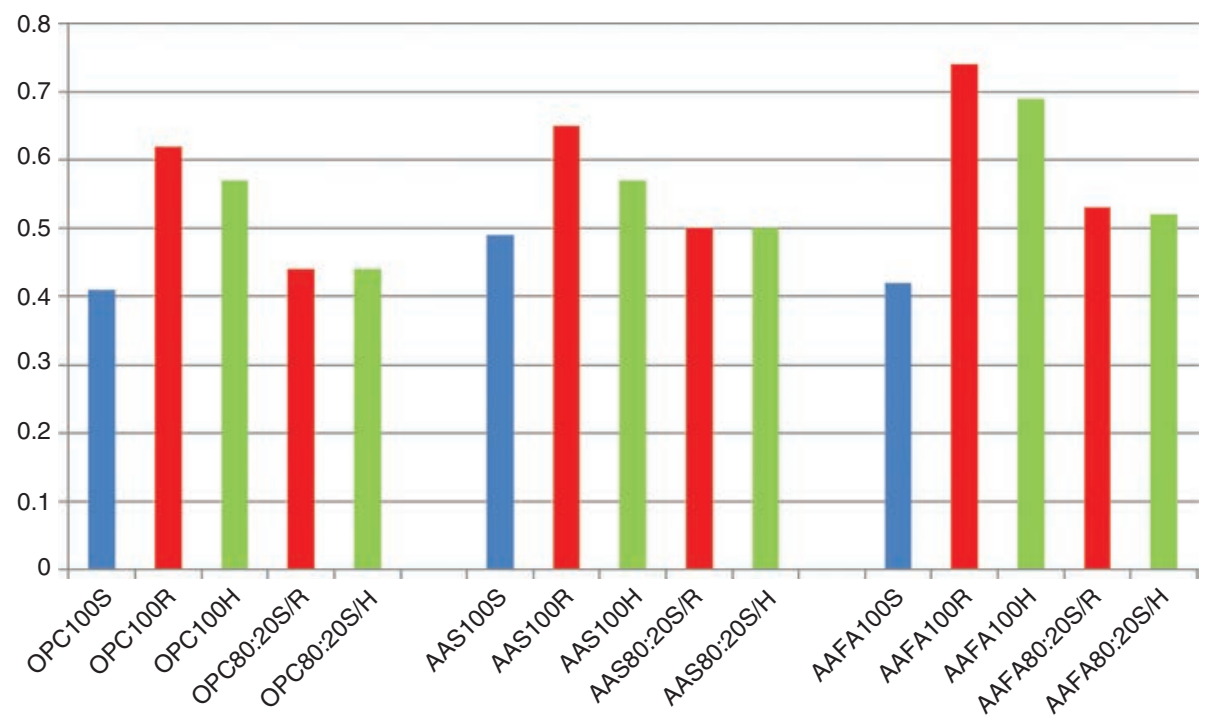

FIGURE 3. Liquid demand for OPC, AAS and AAFA mortars. 
mortars with aggregates $\mathrm{R}$ and $\mathrm{H}$, despite the higher water absorption (Table 5) and greater fineness (Figure 1) in the former.

Moreover, the increase in liquid demand is the highest for mortars with $100 \% \mathrm{R}$ aggregate due to its higher clay conten, higher finesses and therefore its higher water absorption (see Figure 1, Tables 3 and 4). Nevertheless, no relevant differences are observed between $80 / 20 \mathrm{R}$ and $80 / 20 \mathrm{H}$ mortars.

\subsection{Mechanical performance}

The flexural and compressive strength for OPC, AAS and AAFA mortars is shown in Figures 4a-f. Table 7 shows 7 days' porosity and pore size distribution for $100 \% \mathrm{~S}$ and $80 / 20 \%$ replacement mortars. This Figure 4 shows that, generally speaking, in all the mortars tested (OPC, AAS and AAFA) and at all ages, replacing siliceous aggregate $\mathrm{S}$ with $20 \%$
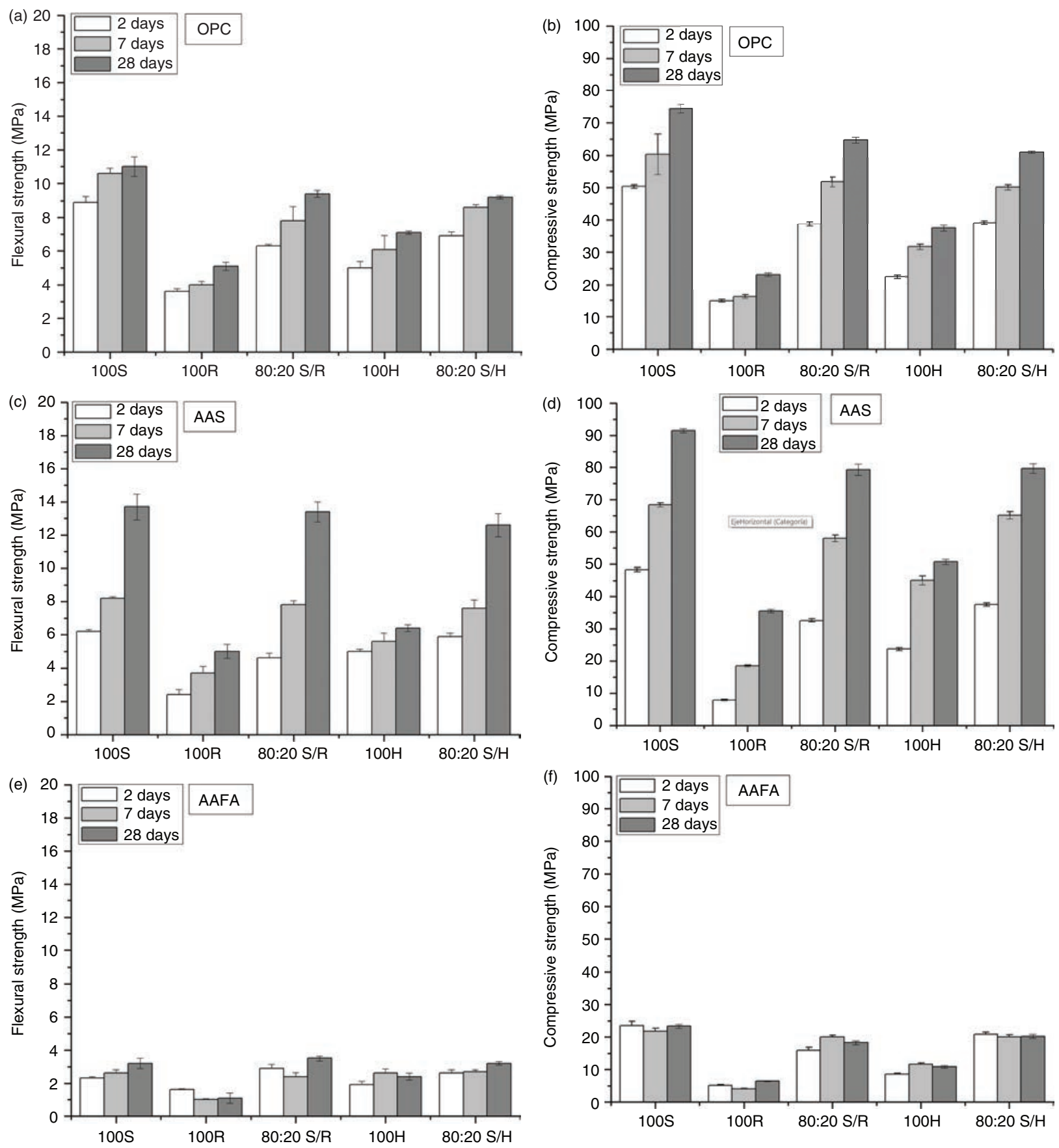

FIGURE 4. OPC, AAS and AAFA mortar flexural and compressive strength (MPa). 
Viability of the use of construction and demolition waste aggregate in alkali-activated mortars $\bullet 7$

TABLE 7. Total porosity and pore size distribution in OPC, AAS and AAFA mortars

\begin{tabular}{|c|c|c|c|c|c|}
\hline \multirow[b]{2}{*}{ Sample } & \multicolumn{4}{|c|}{ Pore Diameter $(\mu \mathrm{m})(\%)$} & \multirow[b]{2}{*}{ Total Porosity (\%) } \\
\hline & $>10$ & 10-0.05 & $0.05-0.01$ & $<0.01$ & \\
\hline OPC100S & 0.69 & 6.30 & 4.73 & 0.11 & 11.83 \\
\hline OPC80:20S/R & 0.82 & 10.55 & 3.95 & 0.18 & 15.50 \\
\hline OPC80:20S/H & 1.58 & 14.57 & 1.70 & 0.14 & 17.99 \\
\hline AAS100S & 1.16 & 3.48 & 1.29 & 0.69 & 6.62 \\
\hline AAS80:20S/R & 1.04 & 3.56 & 1.52 & 2.10 & 8.22 \\
\hline AAS80:20S/H & 1.68 & 4.61 & 1.57 & 0.83 & 8.69 \\
\hline AAFA100S & 2.05 & 12.75 & 0.14 & 0.15 & 15.09 \\
\hline AAFA80:20S/R & 1.00 & 15.03 & 2.09 & 0.16 & 18.28 \\
\hline AAFA $80: 20 \mathrm{~S} / \mathrm{H}$ & 1.41 & 9.20 & 3.94 & 0.11 & 14.66 \\
\hline
\end{tabular}

or $100 \%$ of recycled aggregate induced a decline in mechanical strengths.

Strength grows in all the OPC mortars (Figures $4 \mathrm{a}$ and $4 \mathrm{~b})$ with test time. Total replacement $(100 \%)$ of aggregate $\mathrm{S}$ declined flexural and compressive strength around $70 \%$ for $\mathrm{R}$ aggregate and around $60 \%$ for $\mathrm{H}$ aggregate. These effects are attributables to the higher water demand in the mortars with $100 \%$ recycled aggregate, which would concur with earlier reports (10) (13). Mortars with $100 \%$ of $\mathrm{R}$ aggregate show the lower mechanical performance, due to its clay nature and higher water demand.

A number of authors have reported that the replacement of natural with recycled aggregate in OPC concrete induced a downturn of 5 to $76 \%$ in mechanical strength for replacement ratios of $100 \%$ (14) (40). Such a wide variation would be due to the host of factors that affect strength in concrete bearing recycled aggregate, including $1 / \mathrm{s}$ ratio; nature, particle size distribution and shape of the aggregate; number of reuses; replacement ratio; and type of aggregate replaced. In mortars in which sand was replaced, behaviour was also found to vary widely, particularly when the finest fraction was involved (38).

However, partial $(20 \%)$ replacement of aggregate $\mathrm{S}$ lowered 7 and 28-day compressive strength by only around $15 \%$. Note that the percentage decline in mechanical strength was lower than the aggregate replacement rate applied $(20 \%$ of $\mathrm{S}$ and $15 \%$ decline). Total porosity climbed in the OPC mortars with the replacement of $20 \% \mathrm{~S}$ by $\mathrm{R}$ and $\mathrm{H}$ (see Table 7); while the rise was greater with aggregate $H$ than $R$, the $1 / \mathrm{s}$ ratio was the same in both. The especially steep rise observed in air pores $(>10 \mu \mathrm{m})$ and macropores $(10-0.05 \mu \mathrm{m})$ with $20 \%$ replacements may explain the decline in compressive strength in the mortars prepared with aggregates $\mathrm{R}$ and $\mathrm{H}$.

As in the OPC mortars, flexural and compressive strength in AAS mortars (Figures $4 c$ and 4d) was observed to rise with test time. Moreover, almost all the 7 and 28 day strength values were higher in all the AAS mortars than in the respective OPC materials, a finding likewise consistent with prior studies (41) (42) (43). As observed in OPC mortars, total replacement at 28-days curing, induces a decline in mechanical strength around $60-80 \%$, and again, AAS100R mortars present worst performance. Seven-day mechanical strength declined by 15 and $5 \%$ when the standardised aggregate was partially replaced with $20 \% \mathrm{R}$ and $\mathrm{H}$, respectively. In the 28 day materials, the decline evened out at around 13\% for both types of aggregate. Again as in OPC mortars, the slide in compressive strength was less steep than the aggregate replacement ratio, affording proof of the viability of using recycled aggregate in these AAS mortars. Since the liquid/solid ratio was not observed to change, however, these declines may be associated with alterations in mortar microstructure and compactness. In the AAS mortars, despite the flat $1 / \mathrm{s}$ ratio, total porosity was observed to rise, with increases in the percentages of macropores $(10-0.05 \mu \mathrm{m})$ and mesopores $(0.05-0.01 \mu \mathrm{m})$ in the mortars containing aggregates $\mathrm{R}$ and $\mathrm{H}$. The mortar bearing $20 \%$ aggregate $\mathrm{H}$ exhibited the highest porosity.

Figures $4 \mathrm{e}$ and $4 \mathrm{f}$ show mechanical performance in mortars AAFA. Strength was much lower in these mortars than in the other two at all the ages studied (44). In the 28 day specimens, $100 \%$ replacement of siliceous aggregate by $\mathrm{R}$ or $\mathrm{H}$ aggregates induces a steep decline in compressive strength $(72 \%$ and $56 \%$ for $\mathrm{R}$ and $\mathrm{H}$ respectively). For 7 day specimens (20\% replacement) compressive strength dipped by $15-18 \%$ with both types of recycled aggregate. The 28 day values $(20 \%$ replacement) were comparable or even slightly greater than in the mortars with standardised aggregate. Lastly, despite the 25\% higher liquid demand in the AAFA mortars with $20 \%$ replacement, porosity values rose only slightly or not at all, so mechanical strength are not so dramatically affected. 
The graph in Figure 5 plots the 7 day values for the three variables studied (compressive strength, 1/s ratio and porosity) in the OPC, AAS and AAFA mortars with $20 \%$ replacement. As the graph shows, since the starting materials (OPC, S and FA) differed widely, the resulting mortars occupied different regions in space.

- In OPC mortars the 20\% replacement of aggregate $\mathrm{S}$ with aggregates $\mathrm{R}$ and $\mathrm{H}$ raised the liquid demand by $5 \%$ and induced a $15 \%$ decline in mechanical strength. The upturn in the $1 / \mathrm{s}$ ratio also led to higher mortar porosity $(30-55 \%)$. Here, the dip in strength and rise in porosity appeared essentially to be the result of the higher amount of liquid needed in mortars containing recycled aggregate.

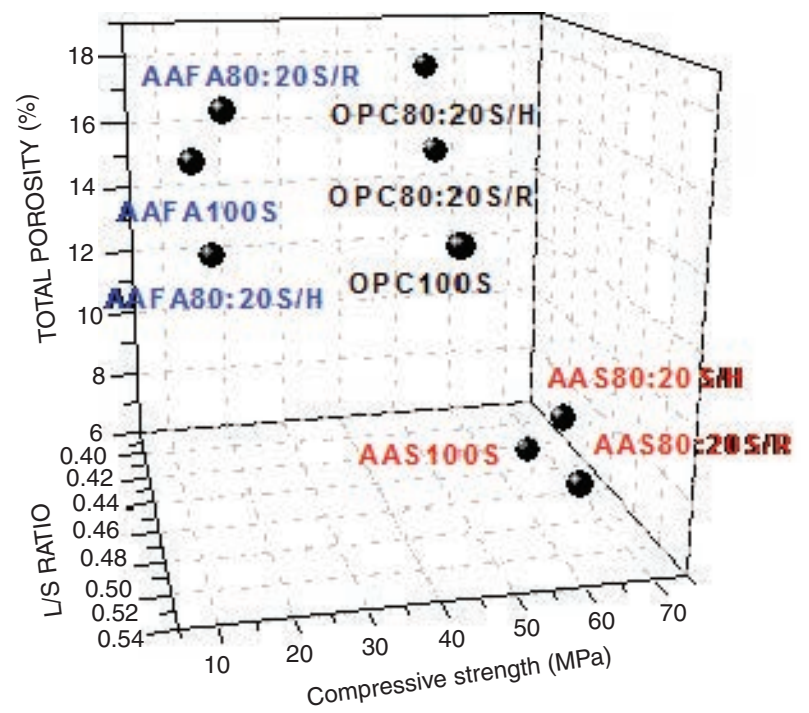

FIGURE 5. L/s ratio, compressive strength and total porosity in OPC, AAS and AAFA mortars.

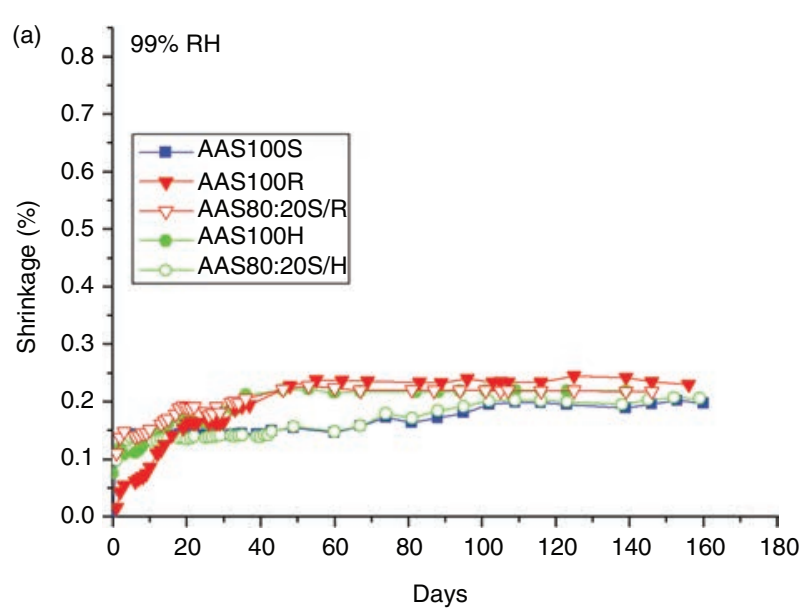

- In AAS mortars, although the 20\% replacement of aggregate $\mathrm{S}$ induced no change in the $1 / \mathrm{s}$ ratio, strength decreased by $15 \%$, nearly the same value as observed in OPC mortars. Although the liquid demand did not rise, porosity climbed by $25-32 \%$, with no significant differences between the mortars bearing aggregates $\mathrm{R}$ and $\mathrm{H}$. Here the decline in strength was not the result of the amount of liquid used, but rather appeared to be related to the compositional differences between the siliceous $\mathrm{S}$ and the calcareous $\mathrm{R}$ and dolomitic $\mathrm{H}$ and the nature of the activating solution.

- In AAFA mortars the presence of 20\% aggregate $\mathrm{R}$ or $\mathrm{H}$ raised the $1 / \mathrm{s}$ ratio by $25 \%$ and lowered compressive strength at a rate equivalent to the declines recorded for the OPC and AAS mortars. In addition, porosity rose by $20 \%$ in the mortar with aggregate $\mathrm{R}$. One possible interpretation of these results would be that despite the greater amount of liquid needed by aggregates $\mathrm{R}$ and $\mathrm{H}(25 \%)$, the N-A-S-H gel generated by ash activation was able to absorb or take up the excess liquid into its three-dimensional structure, whereby the effects on porosity and mechanical strength were not as great as would be expected.

\subsection{Shrinkage behavior of AAS mortars}

The results of the shrinkage tests conducted at 99 and $45 \%$ RH on AAS mortars containing only siliceous (S) or recycled aggregate $(\mathrm{R}$ or $\mathrm{H})$ or $\mathrm{S}$ with $20 \%$ aggregate $\mathrm{R}$ or $\mathrm{H}$ are shown in Figure 6.

Note that when the test was conducted at $99 \%$ $\mathrm{RH}$, the AAS mortar specimens exhibited similar behavior for $\mathrm{S}$ and $\mathrm{H}$ aggregate, with slightly higher shrinkage than observed in prior studies (45). However, higher shrinkage values were found for mortars containing $\mathrm{R}$ aggregate, as expected. The

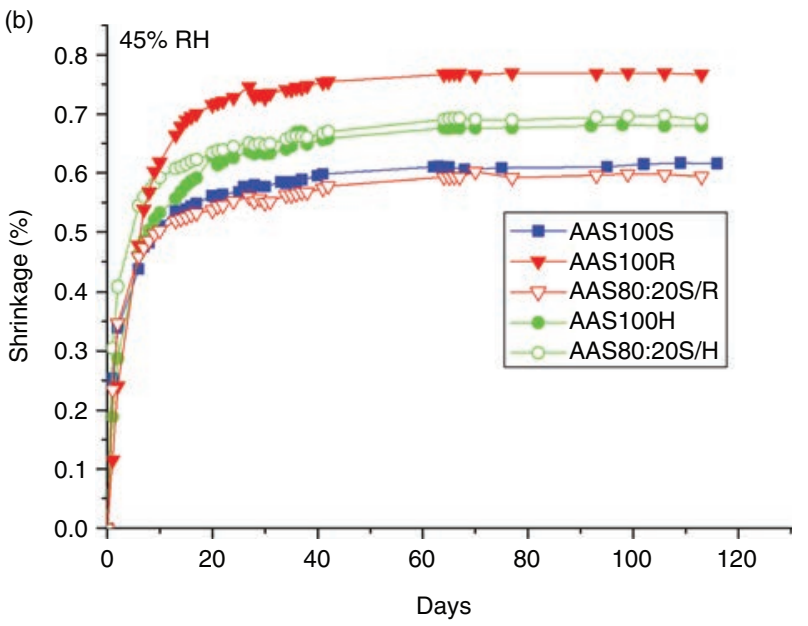

FIgURE 6. a) Autogenous and b) drying shrinkage in AAS mortars. 
drying shrinkage values (test conducted at $45 \% \mathrm{RH}$ ) were higher than found for autogenous shrinkage studies (45). The poorest performance was observed for mortar AAS100R, with total shrinkage of $0.75 \%, 35 \%$ higher than mortars AAS $100 \mathrm{~S}$. AAS100H and AAS80:20S/H mortars presented shrinkage values $20 \%$ higher than AAS100S. The inclusion of recycled aggregates induced an increase in drying shrinkage, and this increase is higher as the replacement rises. These results are in aggrement with previous studies made with OPC concrete (46). However, recent works with AAS systems (47) showed contradictory results, indicating the need of a more in deep study on the effect of recycled aggregate in these alkaline systems.

Regarding mortars with $20 \%$ of recycled aggregate, higher shrinkage was found for AAS80:20S/H which was found to the most porous AAS mortar (see Table 7). Further to these findings, the inclusion of $100 \%$ of construction and demolition waste aggregate increased drying shrinkage.

\subsection{Fire resistance of AAFA mortars}

Lastly, Table 8 gives the percentage of weight loss in AAFA mortars after exposure to high

TABLE 8. Weight loss (\%) after exposure to heat

\begin{tabular}{lcrrrrr}
\hline & \multicolumn{7}{c}{ Temperature $\left({ }^{\circ} \mathbf{C}\right)$} \\
\hline AAFA100S & $\mathbf{5 0}$ & \multicolumn{1}{c}{$\mathbf{2 0 0}$} & $\mathbf{4 0 0}$ & $\mathbf{6 0 0}$ & $\mathbf{8 0 0}$ & $\mathbf{1 0 0 0}$ \\
AAFA100R & 3.34 & 2.35 & 3.08 & 3.10 & 3.21 & 5.80 \\
AAFA80:20S/R & 2.32 & 3.16 & 6.60 & 8.47 & 11.22 & 11.46 \\
AAFA100H & 4.09 & 7.90 & 9.55 & 17.83 & 31.03 & 33.29 \\
AAFA80:20S/H & 2.46 & 3.19 & 4.28 & 6.13 & 10.1 & 10.90 \\
\hline
\end{tabular}

(a) (b)

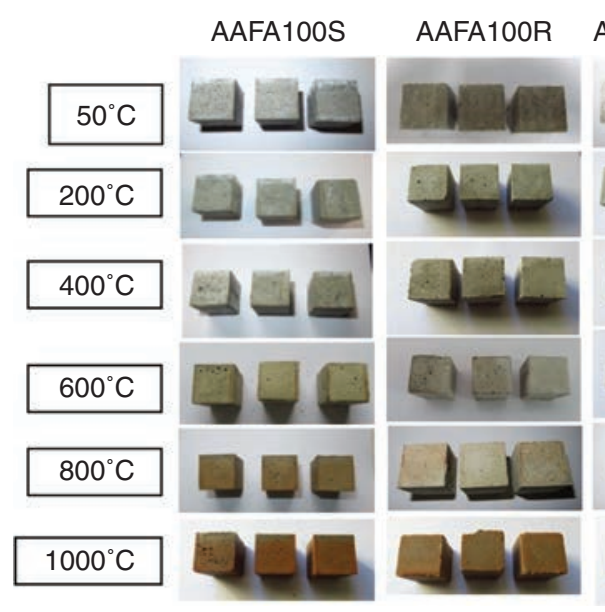

temperatures in the durability test. The photographs in Figure 7 depict the mortar specimens after testing at $200-1000{ }^{\circ} \mathrm{C}$. Specimens from AAFA100R ans AAFA100H were more damaged. The AAFA100S specimens were in best condition, with fewest cracks and least weight loss. Their colour also darkened more than in the other two materials. The AAFA100H and AAFA80:20S/H specimens were in the poorest condition, with lowest density and the highest detachment rate, due to their highest weigth loss (Table 8).

Such greater loss in mortars with recycled aggregates was due in all likelihood to the calcareous nature of the replacement aggregates. At temperatures of over $600{ }^{\circ} \mathrm{C}$ these aggregates lost a substantial portion of their mass due to thermal decomposition.

Mortar with $100 \%$ of aggregattes R or H exhibited very poor behaviour for fire test. However, AAFA100S and AAFA mortars with partial replacement of $\mathrm{S}$ aggregate tested for durability exhibited similar compressive strength patterns (Figure 8). At $50{ }^{\circ} \mathrm{C}$, strength was $16 \%$ lower in the mortars bearing aggregates $\mathrm{R}$ and $\mathrm{H}$ than in mortar AAFA100S. Strength values rose in all three mortars at $200{ }^{\circ} \mathrm{C}$, due to higher activation of fly ash, and then declined until reaching $600{ }^{\circ} \mathrm{C}$ to subsequently climb through the end of the test.

This increase in mechanical strength is due to changes in pore size distribution with temperature (48). At $200{ }^{\circ} \mathrm{C}$ strength climbed by $52 \%$ in mortar AAFA100S but only by $25 \%$ in the mortars with 20\% aggregate replacement. This increase in mechanical strength is due to an increase in FA reaction/activation and formation of $\mathrm{N}-\mathrm{A}-\mathrm{S}-\mathrm{H}$ gel up to $200^{\circ} \mathrm{C}$. Other authors have observed this effect until higher temperatures (49). However, at $600{ }^{\circ} \mathrm{C}$, strength dropped in mortar AAFA100S to (c)

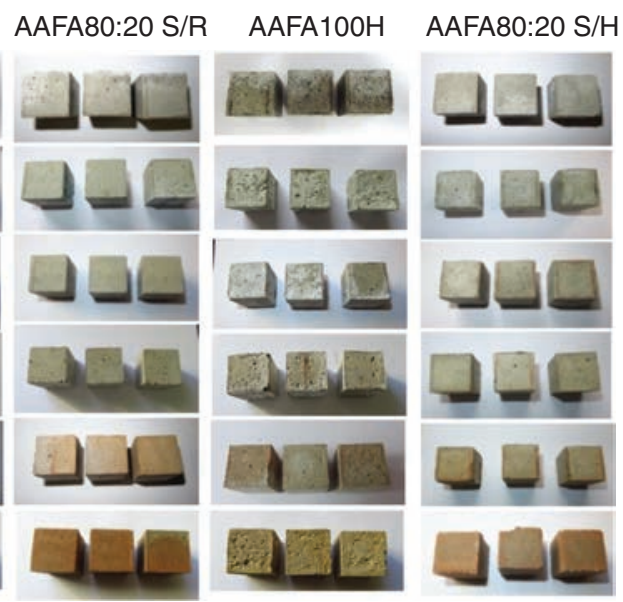

FIGURE 7. AAFA mortar specimens after exposure to high temperatures: a) AAFA100S; b) AAFA100R; c) AAFA80:20S/R, d) AAFA100H and e) AAFA80:20 S/H. 
(a)

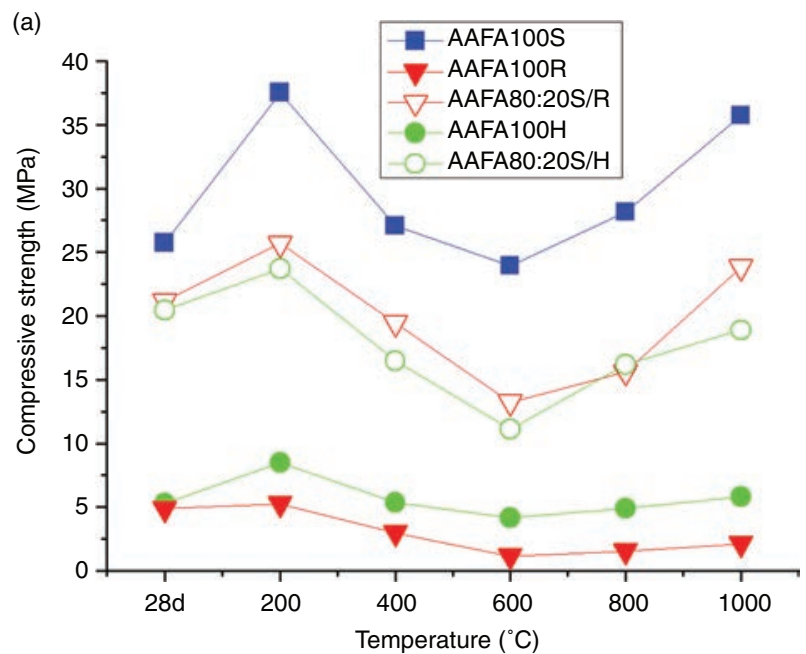

(b)

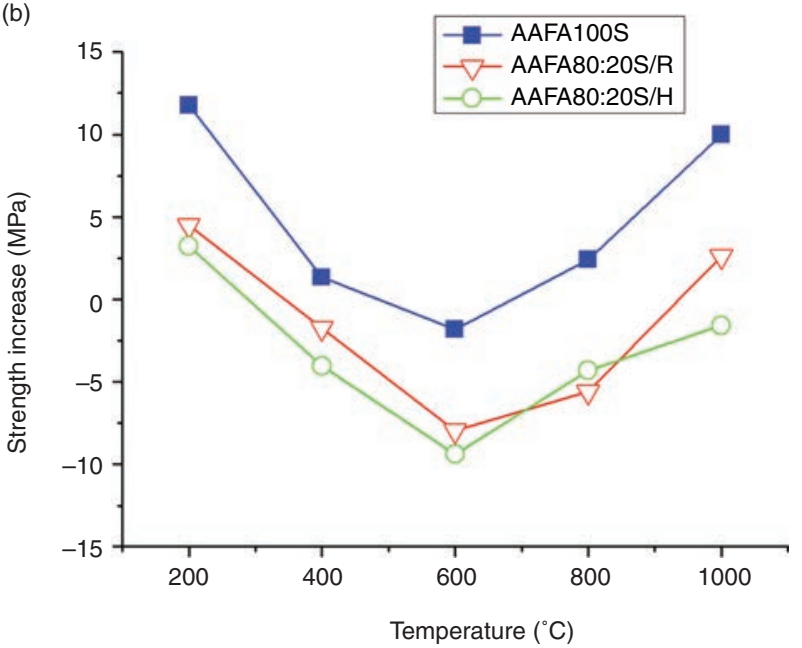

FIGURE 8. Compressive strength in AAFA specimens: a) versus high temperature; b) fluctuation relative to 28 day AAFA mortars.

values comparable to $50{ }^{\circ} \mathrm{C}$. In the recycled aggregate, however, strength was $40 \%$ lower than at $50{ }^{\circ} \mathrm{C}$. According to literature (48) this decline in mechanical strength is due to an increase in porosity, and it is also related with the nature of the zeolites and reacctions product formed. Lastly, at $1000{ }^{\circ} \mathrm{C}$ mortars AAFA100S and AAFA80:20S/R reverted to the $200{ }^{\circ} \mathrm{C}$ values, whereas the mortar with $20 \%$ aggregate $\mathrm{H}$ barely attained its initial strength. At these high temperatures the liquid come into vapour which is released from the material, generating pressure into pore walls and producing the interconection of these pores. However the reaction products can melt, filling these pores and giving stability to specimens (48).

\section{Conclusions}

- The replacement of siliceous aggregate by recycled aggregates increases liquid demand for OPC, AAS and AAFA mortars, and this increment is higher as the replacement percentage raises. The AAFA mortars are the ones with the highest in 1/s ratio as a result of the incorporation of recycled aggregates.

- The increase in liquid demand is the highest for mortars with $100 \% \mathrm{R}$ aggregate due to its higher clay content, higher finesses and therefore its higher water absorption.

- OPC, AAS and AAFA mortars show a steep decrease in compressive strength in $100 \%$ replacement mortars, however for $20 \%$ replacement mortars the percentage decline in mechanical strength was lower than the aggregate replacement rate applied.

- The inclusion of C\&DW waste aggregate on AAS mortars did not induce significant changes on autogenous shrinkage in these mortars, but great changes in drying shrinkage.
- AAFA mortar specimens with $100 \%$ and $20 \%$ replacement, presented higher loss of mass after exposure to high temperatures than AAFA mortars with $\mathrm{S}$ aggregate, due to de decomposition of dolomite and calcite from the recycled aggregates. After fire tests, the mechanical performances in AAFA mortars with recycled aggregates were worse.

- It has been proven the feasibility of partial replacement (up to 20\%) of silicious aggregate by C\&DW aggregates in AAS and AAFA mortars.

\section{Acknowledgements}

This research was funded by the Spanish Ministry of the Economy under project BIA2013-47876-C2-1-P.

\section{REFERENCES}

1. Pacheco-Torgal, F., Labrincha, L. (2013). Review: The future of construction materials research and the seventh UN Millennium Development Goal: A few insights. Construc. Build. Mat., 40: 729-737, https://doi.org/10.1016/j. conbuildmat.2012.11.007

2. Puertas, F., Santos, R., Alonso, M.M., del Río, M. (2015). Alkali-activated cement mortars containing recycled claybased construction and demolition waste. Ceram. Silikaty, 59: $202-210$

3. Müller, H., Haist, M., Vogel, M. (2014). Assessment of the sustainability potential of concrete and concrete structures considering their environmental impact, performance and lifetime. Construc. Build. Mat., 67: 321-337, https://doi. org/10.1016/j.conbuildmat.2014.01.039

4. European Commision, Towards a circular economy, Available: https://ec.europa.eu/commission/priorities/jobsgrowth-and-investment/towards-circular-economy_en. [Last access: july 2017].

5. Palomo, A., Krivenko, P., García-Lodeiro, I., Kavalerova, E., Maltseva, O., Fernández-Jimenez, A. (2014). A review on alkaline activation: new analytical perspectives. Mater. Construcc., 64, [315] e022. https://doi.org/10.3989/ mc.2014.00314 
6. Provis, J., Palomo, A., Shi, C. (2015). Advances in understanding alkali-activated materials. Cem. Concr. Res. 78: 110-125, https://doi.org/10.1016/j.cemconres.2015. 04.013

7. Villaquirán-Caicedo, M., Mejía de Gutierrez, R., Gallego, N. (2017). A Novel MK-based Geopolymer Composite Activated with Rice Husk Ash and KOH: Performance at High Temperature. Mater. Construcc. 67, [326] e117, https:// doi.org/10.3989/mc.2017.02316

8. Fernández-Jimenez, A., Puertas, F. (197). Alkali-activated slag cements: Kinetic studies. Cem. Concr. Res. 27: 359-368, https://doi.org/10.1016/S0008-8846(97)00040-9

9. Puertas, F., Palacios, M., Manzano, H., Dolado, J., Rico, A., Rodríguez, J. (2011). A model for the C-A-S-H gel formed in alkali-activated slag cements, J. Europ. Cer. Soc., 31: 20432056. https://doi.org/10.1016/j.jeurceramsoc. 2011.04.036

10. Martín Morales, M. (2013). El residuo de construcción y demolición (RCD) como árido en la elaboración de prefabricados no estructurales. $\mathrm{PhD}$ Thesis. Univ. Granada (In spanish)

11. Vegas, I., Ibañez, J., Lisbona, A., Sáez de Cortazar, A., Frías, M. (2011). Pre-normative research on the use of mixed recycled aggregates in unbound road sections. Construc. Build. Mat. 25., [5], 2674-2682, https://doi.org/10.1016/j. conbuildmat.2010.12.018

12. Fernández-Ledesma, E., Jiménez, J., Ayuso, J., Corinaldesi, V., Iglesias-Godino, F. (2016). A proposal for the maximum use of recycled concrete sand in masonry mortar design. Mater. Construcc., 66, [321] e075.

13. Shi, X., Collins, F., Zhao, X., Whang, Q. (2012). Mechanical properties and microstructure analysis of fly ash geopolymeric recycled concrete. J. Haz. Mater, 237-238, 20-29. https://doi. org/10.1016/j.jhazmat.2012.07.070

14. Behera, M., Bhattacharyya, S., Minocha, A., Deoliya, R., Maiti, S. (2014) Recycled aggregate from C\&D waste \& its use in concrete. A breakthrough towards sustainability in construction sector. A review, Construc. Build. Mat. 68: 501-516. https://doi.org/10.1016/j.conbuildmat.2014.07.003

15. Puertas, F., Barba, A., Gazulla, M., Gómez, M., Palacios, M., Martínez-Ramirez, S. (2006). Ceramic wastes as raw materials in portland cement clinker fabrication. characterization and alkalineactivation. Mater. Construcc., 56: [281], 73-84

16. Allahverdi, A., Kani, E. (2009). Construction waste as raw materials for geopolymer binders. Int. J. Civ. Engin. . 7: [3], 154-160.

17. Reig, L., Tashima, M., Borrachero, M.V., Monzó, J., Cheeseman, C., Payá, J. (2013). Properties and microstructure of alkali-activated red clay brick waste. Construc. Build. Mat, 43: 98-106, https://doi.org/10.1016/j. conbuildmat.2013.01.031

18. Robayo-Salazar, R.A., Rivera, J., Mejía de Gutiérrez, R. (2017). Alkali-activated building materials made with recycled construction and demolition wastes. Construc. Build. Mat. 149: 130-138, https://doi.org/10.1016/j. conbuildmat.2017.05.122

19. Rakhimova, N., Rakhimov, R. (2015). Alkali-activated cements and mortars based on blast furnace slag and red clay brick waste. Mat. Desig. 85: 324-331. https://doi. org/10.1016/j.matdes.2015.06.182

20. Shaikh, F. (2016) Mechanical and durability properties of fly ash geopolymer concrete containing recycled coarse aggregates, Int.l J. Sust. Built Envir. 5: 277-287, https://doi. org/10.1016/j.ijsbe.2016.05.009

21. Parthiban, K., Mohan, K.S.R. (2017). Influence of recycled concrete aggregates on the engineering and durability properties of alkali activated slag concrete, Construc. Build. Mat. 133: 65-72. https://doi.org/10.1016/j. conbuildmat.2016.12.050

22. UNE-EN 196-2:2014. Method of testing cement - Part 2: Chemical analysis of cement, 2014.

23. UNE-EN 80243, 1999. Cement test metyhods. Chemical analysis. Determination of free calcium oxyde: ethylenglycol method.

24. Hooton, R., Emery, J. (1983). Glass content determination and strength development predictions for vitrified blast furnace slag. 1st Int. Conf. on the fly ash, silica fume, slag and other mineral by products in concrete, Montebello, Quebec, Canada.

25. Arjuman, P., Silbee, M., Roy, D. (1997). Quantitative determination of the crystalline and amorphous phases in low calcium fly ash, 10th International Congress on the Chemistry of Cement, Gotheburg.

26. UNE 80122:1991, Methods of testing cement. Determination of fineness (Blaine method).

27. UNE-EN-1744-1, 1999. Tests for chemical properties of aggregates. part 1: chemical analysis.

28. UNE-80-217:91, 1991. Methods of testing cement. Determination of chloride, carbon dioxide and alkali content.

29. Valverde-Espinosa, I. (1993). Caracterización de aridos para hormigón en la depresión de Granada, PhD Thesis. Univ. Granada (In spanish)

30. Valverde-Espinosa, I. (2014). Los áridos carbonatados de Granada en relación con algunas prescripciones de la EH-91, Technical report (in spanish).

31. EN-1097-6:2001/A1:2006, Tests for mechanical and physical properties of aggregates Part 6: Determination of particle density and water absorption.

32. UNE-EN 933-1: 2012, Tests for geometrical properties of aggregates - Part 1: Determination of particle size distribution - Sieving method.

33. UNE-EN196-1, 2011 Methods of testing cements. Determination of strength.

34. Puertas, F., Varga, C., Alonso, M.M. (2014). Rheology of alkali-activated slag pastes. Effect of the nature and concentration of the activating solution, Cem. Concr. Comp.,53,. 279-288. https://doi.org/10.1016/j. cemconcomp.2014.07.012

35. Palacios, M., Banfill, P., Puertas, F. (2008). Rheology and setting of alkali-activated slag pastes and mortars: Effect of organic admixture, ACI Mater. J, 105: 140-148.

36. Alonso, M.M., Gismera, S., Blanco, M.T., Lanzón, M., Puertas, F. (2017). Alkali-activated mortars: Workability and rheological behaviour. Construc. Build. Mat. 145: 576587. https://doi.org/10.1016/j.conbuildmat.2017.04.020

37. UNE-EN-1015-3: 2000. Methods of test for mortar for masonry. Part 3: Determination of consistence of fresh mortar (by flow table)

38. Silva, R., De Brito, J., Dhir. R.K. (2016). Performance of cementitious renderings and masonry mortars containing recycled aggregates from construction and demolition wastes. Construc. Build. Mat. 105: [15] 400-415. https://doi. org/10.1016/j.conbuildmat.2015.12.171

39. Corinaldesi, V., Moriconi, G. (2009). Behaviour of cementitious mortars containing different kinds of recycled aggregate. Construc. Build. Mat. 23: 289- 94. https://doi. org/10.1016/j.conbuildmat.2007.12.006

40. Yildrim, S., Meyer, C., Herfellner, S. (2015). Effects of internal curing on the strength, drying shrinkage and freezethaw resistance of concrete containing recycled concrete aggregates. Construc. Build. Mat. 91: 288-296. https://doi. org/10.1016/j.conbuildmat.2015.05.045

41. Angulo-Ramírez, D., Mejía de Gutiérrez, R., Puertas, F. (2017). Alkali-activated Portland blast-furnace slag cement: Mechanical properties and hydration. Construc. Build. Mat.140: 119-128. https://doi.org/10.1016/j.conbuildmat. 2017.02.092

42. Fernández-Jiménez, A., Palomo, J.G., Puertas, F. (1999). Alkali-activated slag mortars: Mechanical strength behaviour. Cem. Concr. Res. 29, [8]: 1313-1321, https://doi. org/10.1016/S0008-8846(99)00154-4

43. Puertas, F., Torres-Carrasco, M. (2014). Use of glass waste as an activator in the preparation of alkali-activated slag. Mechanical strength and paste characterisation," Cem. Concr. Res. 57: 95-104. https://doi.org/10.1016/j.cemconres. 2013.12.005

44. Luna-Galiano, Y., Fernández-Pereira, C., Izquierdo, M. (2016). Contributions to the study of porosity in fly ashbased geopolymers. Relationship between degree of reaction, porosity and compressive strength. Mater. Construcc., 66: [324], e098. https://doi.org/10.3989/mc.2016.10215 
45. Palacios, M: Puertas, F. (2007). Effect of shrinkage-reducing admixtures on the properties of alkali-activated slag mortars and pastes. Cem. Concr. Res. 37: 691-702. https:// doi.org/10.1016/j.cemconres.2006.11.021

46. Medjigbodo, S., Bendimerad, A., Roziere, E., Loukili, A. (2018). How do recycled concrete aggregates modify the shrinkage and self-healing properties?. Cem. Concr. Comp. 86: 72-86. https://doi.org/10.1016/j.cemconcomp. 2017.11.003

47. Lee, N., Abate, S., Kim, H-K. (2018). Use of recycled aggregates as internal curing agent for alkali-activated slag system. Construc. Build. Mat. 159: 286-296. https://doi. org/10.1016/j.conbuildmat.2017.10.110

48. Martin, A., Pastor, J., Palomo, A., Fernández-Jimenez, A (2015). Mechanical behaviour at high temperature of alkaliactivated aluminosilicates (geopolymers), Construc. Build. Mat. 93: 1188-1196. https://doi.org/10.1016/j.conbuildmat. 2015.04.044

49. Pan, Z., Tao, Z., Cao, Y., Wuhrer, R., Murphy, T. (2018). Compressive strength and microstructure of alkali-activated fly ash/slag binders at high temperature. Cem. Concr. Comp. 86: 9-18, https://doi.org/10.1016/j.cemconcomp.2017.09.011 